\title{
lodometric determination of ascorbic acid in bulk and Vitamin-C tablets using Potassium lodate
}

\begin{abstract}
Ascorbic acid is one of the major water soluble vitamin and many health benefits have been attributed to ascorbic acid such as antioxidant, anti-atherogenic,immunomodulator anti-carcinogenic etc. It plays a vital role in the biosynthesis of collagen, carnitine and neurotransmitters. As humans can not produce ascorbic acid due to the lack of an enzyme gulonolactone oxidase, it has to be supplemented mainly through fruits, vegetables and tablets. In this present work, we have reported a simple, cost effective, reliable titrimetric method for the estimation of ascorbic acid present in commercially available Vit-C tablets and also the determination of molecular weight of ascorbic acid. The method involves the oxidative dehydrogenation of ascorbic acid by potassium iodate followed by the determination of unreacted potassium iodate by iodometry.
\end{abstract}

Keywords: ascorbic acid, Vitamin-C tablets, molecular weight, potassium iodate, iodometric method
Volume 8 Issue 3 - 2020

\author{
Sowmya PT,' Anitha Sudhir,' K M Lokanatha \\ Rai, $^{2}$ HN Deepakumari ${ }^{3}$ \\ 'Department of Chemistry,Vidyavardhaka College of \\ Engineering, India \\ ${ }^{2}$ Department of Studies in Chemistry, University of Mysore, \\ India \\ ${ }^{3}$ Department of Chemistry, Bharathi College, India
}
Correspondence: Sowmya PT, Department of Chemistry, Vidyavardhaka College of Engineering, Mysuru-570002 Karnataka, India, Tel +919008196715,
Email ptsowmya8@gmail.com

Received: May 01, 2020 | Published: June 10, 2020

\section{Introduction}

Ascorbic acid is one of the water soluble vitamins. It is widely distributed in both plants and animals and its role in disease prevention and cure. ${ }^{1-3}$ Most of the plants and animals synthesize ascorbic acid from D-glucose or D-galactose. It is used for the vitamination of various types of food and beverages. Ascorbic acid is widely, especially in the pharmaceutical preparation as tablets, capsules, crystalline powder, effervescent tablets,chewable tablets and liquid form and in the chemical analysis. Various methods have been reported in the literature for the determination of ascorbic acid like potentiometric, ${ }^{4}$ reductometric, ${ }^{5}$ thermometric, ${ }^{6}$ colorimetric,,${ }^{7,8}$ paper chromatograpy, ${ }^{9}$ Spectrophotometry, ${ }^{10}$ Aurelia Magdalena Pisoschi reported the ascorbic acid determination in commercial fruit juice samples by cyclic voltammetry. ${ }^{11}$ Senon reported bromochlorohydantoin as titrant for the potentiometric estimation of ascorbic acid. ${ }^{12}$ Mohammed Idaan Hassan AL Majidi reported the determination of ascorbic acid in various fruit and vegetable by UVspectrophotometry method. ${ }^{13,14}$ Earlier Rai et al successfully utilized chloramine-T for the determination of molecular weight of amino acids and ascorbic acid. ${ }^{15}$ For the estimation of ascorbic acid we have developed a simple titrimetric method using potassium iodate which is presented in this paper. The method reported makes use of the fact that ascorbic acid is known to undergo oxidative dehydrogenation by potassium iodate to dehydroascorbic acid involving one molecules of chloramine-T per molecule of ascorbic acid.

\section{Reagents}

All the common reagents procured from commercial supplies were used as such without any purification. Distilled water was used throughout the experiment. Vitamin-C tablets containing Ascorbic acid in the range of 100-500 mg were used. Potassium iodate and Ascorbic acid procured were of Analytical grade reagents.

\section{Experimental procedure}

In a typical experiment, a known excess of standard solution of potassium iodate is added to a known amount of ascorbic acid. After completion of the reaction, unreacted Potassium iodate is determined by iodometry. By carrying out a blank experiment simultaneously, the amount of potassium iodate consumed is determined. As the overall reaction requires one mole of CAT per molecule of ascorbic acid, which is equivalent to one mole of iodine, the molecular weight ' $\mathrm{m}$ ' of the ascorbic acid is determined using the equation (1):

$$
m=\frac{2000 W}{\left(V_{1}-V_{2}\right) M}
$$

where $M$ - molarity of sodium thiosulphate, $V_{1}$ and $V_{2}$-volume of sodium thiosulphate consumed for experimental and blank titration. $W$ - weight of ascorbic acid/ tablet taken.

\section{Determination of molecular weight of ascorbic acid.}

An accurately weighed $(20-60 \mathrm{mg})$ sample of an ascorbic acid was dissolved in distill water $(10 \mathrm{ml})$ in Erlenmeyer flask. To this, a solution $0.01 \mathrm{~mol}$ of potassium iodate $(40 \mathrm{ml})$ was added. The reaction mixture was shaken well and kept aside at room temperature for about $30 \mathrm{~min}$, after which $2 \mathrm{~N}$ sulphuric acid $(1 \mathrm{ml}), 10 \%$ potassium iodide $(1 \mathrm{ml})$ and water $(2 \mathrm{ml})$ were added and liberated iodine was titrated against standard sodium thiosulphate solution $(0.01 \mathrm{M})$ using starch as an indicator. In a similar way, a blank titration was conducted without adding ascorbic acid or ascorbic acid containing vitamin-C tablets. From the difference in the volume of sodium thiosulphate solution consumed, the molecular weight ' $\mathrm{m}$ ' was calculated using equation (1)

\section{Estimation of ascorbic acid in pharmaceutical vitamin tablets}

A known amount of sample in the range of $10-60 \mathrm{mg}$ of wellpowdered vitamin tablets containg ascorbic acid in the range of 100$500 \mathrm{mg}$ was dissolved in distilled water $(10 \mathrm{ml})$ in an Erlenmeyer flask and then a solution of $0.01 \mathrm{~mol}$ of potassium iodate $(40 \mathrm{ml})$ was added. The reaction mixture was shaken well and kept aside at room temperature for about 30 min followed by the addition of $2 \mathrm{~N}$ sulfuric acid $(1 \mathrm{ml}), 10 \%$ potassium iodide $(1 \mathrm{ml})$ and water $(2 \mathrm{ml})$ and 
the liberated iodine was titrated against standard sodium phosphate solution $(0.01 \mathrm{M})$ using starch as an indicator. Similarly, a blank titration was conducted without adding ascorbic acid or ascorbic acid containing vitamin-C tablets. From the difference in the volume of sodium thiosulphate solution consumed, the amount of ascorbic acid ' $W$ ' present in vitamin-C tablets was calculated using the following equation:

$$
W=\frac{\mathrm{m}\left(\mathrm{V}_{1}-\mathrm{V}_{2}\right) M}{2000}
$$

where $M$ - molarity of sodium thiosulphate, $V_{1}$ and $V_{2}$-volume of sodium thiosulphate consumed for experimental and blank titration, $\mathrm{m}$-molecular weight of the ascorbic acid.

\section{Results and discussion}

The method describes the determination of molecular weight of ascorbic acid and estimation of the amount of ascorbic acid present in vitamin-C tablets. The method reported here is much simpler than the literature method. It can also be observed that by this method the standard deviation for the theoretical and experimental values was less than 1 with respect to the molecular weight of the ascorbic acid (Table 1).

The relative percentage errors with respect to the amount of ascorbic acid present in vitamin-C tablets were found to be less than $2 \%$ and are given in Table 2. (The relative error was calculated from the experimental values and the amount of ascorbic present was specified by the manufacturers of the pharmaceutical tablets).

Reaction Mechanism involved is shown in the Scheme 1. From the mechanism, it is evident that the reactive site involved in the attack of potassium iodate is the ene-diol group. This group is more reactive than other functional groups. Therefore, in the presence of other materials, potassium iodate first reacts with ascorbic acid and the rest needs more time to react under the experimental condition. Hence, we have not found any interference of the other foreign materials.

Table I Molecular weight of ascorbic acid (theoretical molecular weight of ascorbic acid is 176.13)

\begin{tabular}{|c|c|c|c|c|c|c|c|c|}
\hline \multirow{3}{*}{ Time (min) } & \multicolumn{6}{|c|}{ Experimental values } & \multirow{3}{*}{ Average } & \multirow{3}{*}{ Standard deviation } \\
\hline & \multicolumn{6}{|c|}{ Trial number } & & \\
\hline & I & 2 & 3 & 4 & 5 & 6 & & \\
\hline \multirow{3}{*}{30} & 176.47 & 176.4 & 176.37 & 176.45 & 175.9 & 175.7 & 176.12 & 0.34 \\
\hline & $(30.0)$ & $(40.0)$ & $(50.10)$ & (37.30) & (58.04) & (39.52) & & \\
\hline & 7 & 8 & 9 & 10 & II & 12 & & \\
\hline \multirow{2}{*}{30} & 176.05 & 176.3 & 176.2 & 176.25 & 175.98 & 176.1 & 176.15 & 0.12 \\
\hline & $(52.06)$ & $(49.70)$ & $(55.02)$ & $(46.70)$ & $(43.50)$ & $(28.60)$ & & \\
\hline
\end{tabular}

*The values given in the brackets were the amount of ascorbic acid taken in each trial

Table 2 The amount of ascorbic found in pharmaceutical tablets containing ascorbic acid

\begin{tabular}{|c|c|c|c|c|c|c|c|c|}
\hline $\begin{array}{l}\text { Name of } \\
\text { the tablet }\end{array}$ & $\begin{array}{l}\text { Trial } \\
\text { No. }\end{array}$ & $\begin{array}{l}\text { Amount } \\
\text { taken (mg) }\end{array}$ & $\begin{array}{l}\text { Amount } \\
\text { Found (mg) }\end{array}$ & $\begin{array}{l}\text { Relative } \\
\text { error* (\%) }\end{array}$ & $\begin{array}{l}\text { Name of } \\
\text { the tablet }\end{array}$ & $\begin{array}{l}\text { Amount } \\
\text { taken (mg) }\end{array}$ & $\begin{array}{l}\text { Amount } \\
\text { found (mg) }\end{array}$ & $\begin{array}{l}\text { Relative } \\
\text { error* (\%) }\end{array}$ \\
\hline I & 2 & 3 & 4 & 5 & 6 & 7 & 8 & 9 \\
\hline \multirow{6}{*}{ Celin } & I & 51.26 & 51.02 & 0.46 & \multirow[t]{6}{*}{ Limcee } & 58 & 58.07 & 0.12 \\
\hline & 2 & 38.75 & 38.55 & 0.52 & & 64.02 & 64.2 & 0.28 \\
\hline & 3 & 33.11 & 33.34 & 0.69 & & 35.7 & 35.65 & 0.14 \\
\hline & 4 & 41.39 & 41.05 & 0.82 & & 46 & 46.45 & 0.97 \\
\hline & 5 & 48.64 & 48.98 & 0.69 & & 55 & 55.34 & 0.61 \\
\hline & 6 & 46.82 & 46.5 & 0.68 & & 67 & 67.15 & 0.22 \\
\hline & I & 47.1 & 47.22 & 0.25 & \multirow[t]{6}{*}{ Becosule } & 50 & 50.24 & 0.48 \\
\hline & 2 & 38.16 & 38.4 & 0.63 & & 54.2 & 54.34 & 0.26 \\
\hline Cobadex & 3 & 42 & 42.34 & 0.8 & & 39.08 & 39.17 & 0.23 \\
\hline \multirow[t]{3}{*}{ Forte } & 4 & 34.79 & 34.95 & 0.46 & & 45.87 & 45.95 & 0.17 \\
\hline & 5 & 51.75 & 51.46 & 0.56 & & 43.3 & 43.67 & 0.85 \\
\hline & 6 & 39.16 & 39.25 & 0.22 & & 33 & 33.23 & 0.69 \\
\hline
\end{tabular}


Table Continued

\begin{tabular}{|c|c|c|c|c|c|c|c|c|}
\hline $\begin{array}{l}\text { Name of } \\
\text { the tablet }\end{array}$ & $\begin{array}{l}\text { Trial } \\
\text { No. }\end{array}$ & $\begin{array}{l}\text { Amount } \\
\text { taken (mg) }\end{array}$ & $\begin{array}{l}\text { Amount } \\
\text { Found (mg) }\end{array}$ & $\begin{array}{l}\text { Relative } \\
\text { error* (\%) }\end{array}$ & $\begin{array}{l}\text { Name of } \\
\text { the tablet }\end{array}$ & $\begin{array}{l}\text { Amount } \\
\text { taken (mg) }\end{array}$ & $\begin{array}{l}\text { Amount } \\
\text { found (mg) }\end{array}$ & $\begin{array}{l}\text { Relative } \\
\text { error* (\%) }\end{array}$ \\
\hline \multirow{6}{*}{ Supradyn } & I & 42.67 & 43 & 0.77 & & & & \\
\hline & 2 & 33.07 & 33.17 & 0.3 & & & & \\
\hline & 3 & 45.69 & 45.76 & 0.15 & & & & \\
\hline & 4 & 38.99 & 38.87 & 0.3 & & & & \\
\hline & 5 & 31.22 & 31.29 & 0.22 & & & & \\
\hline & 6 & 32 & 32.3 & 0.94 & & & & \\
\hline
\end{tabular}

*Relative error was calculated with respect to the difference of experimental values with the amount present in the tablets:

Relative error $=($ calculated value-experimental $) \times 100 /$ calculated value
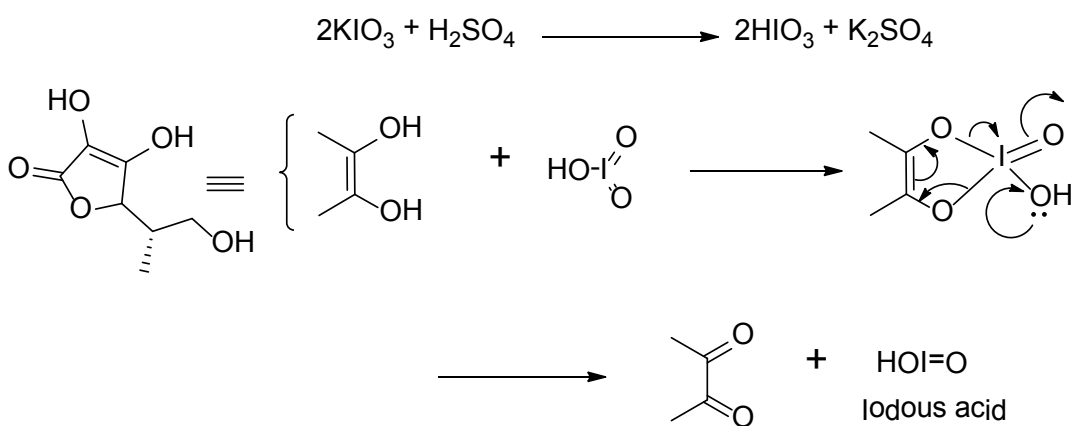

\section{Conclusion}

From the results of this work, we conclude that this titrimetric method determines ascorbic acid instantly, thereby greatly reduces the time of determination with precision and cost-effective.This method of determination of ascorbic acid in multivitamin tablets can be a method of quantitative determination of ascorbic acid.

\section{Acknowledgments}

One of the authors (SPT) is grateful to Vidyavardhaka College of Engineering and the University of Mysore for the lab facilities.

\section{Conflicts of interest}

Authors declare that there is no conflict of interest.

\section{References}

1. Szent Gyorgi A. Observations on the Function of Peroxidase Systems and the Chemistry of the Adrenal Cortex: Description of a New Carbohydrate Derivative. Biochem J. 1928;22(6):13871409.

2. Waught WA, King CG. Isolation and identification of vitamin c. $J$ Biol Chem. 1932;97:325.

3. Shailja Chambial, Shailendra Dwivedi, Kamla Kant Shukla, et al. Vitamin C in Disease Prevention and Cure: An Overview. Indian J Clin Biochem. 2013;28(4):314-328.

4. Spaeth EE, Baptist VH, Martin Roberts. Rapid Potentiometric Determination of Ascorbic Acid. Anal Chem. 1962;34(10):1342.

5. Mapson LW. The estimation of ascorbic acid in the presence of reductones and allied substances. Journal of the Society of Chemical Industry. 1943;62(12):223-232.

6. Bark LS, Grime JK. The Thermometric assay of ascorbic acid. Analyst. 1974;99:38-42.
7. Jagota SK, Dani HM. A new colorimetric technique for the estimation of vitamin C using Folin phenol reagent. Analytical Biochemistry. 1982;127(1):178-182.

8. Elnenaey ES, Soliman R. A sensitive colorimetric method for estimation of ascorbic acid. Talanta. 1979;26(12):1164-1166.

9. Yu-Tuan Chen, Isherwood FA, Mapson LW. Quantitative estimation of ascorbic acid and related substances in biological extracts by separation on a paper chromatogram. Journal of the Society of Chemical Industry.1953;55(5):821-823.

10. Hewitt EJ, Dickes GJ. Spectrophotometric measurements on ascorbic acid and their use for the estimation of ascorbic acid and dehydroascorbic acid in plant tissues. Biochem J. 1961;78(2):384391.

11. Pisoschi AM, Danet AF, Kalinowski S. Ascorbic Acid Determination in Commercial Fruit Juice Samples by Cyclic Voltammetry. J Autom Methods Manag Chem. 2008;200:937651.

12. Indrasenan $P, \quad$ Radhamma Potentiometric Determinations using Bromochlorohydanton as a New Oxidimetric Titrant. Indian J Chem. 1983;22A:729-730.

13. AL Majidi MH, Y-ALQubury H. Determination of Vitamin $\mathrm{C}$ (ascorbic acid) Contents in various fruit and Vegetables by UV-Spectrophotometry and titration methods. JCHPS. 2016;9(4):2972-2974.

14. Fontannaz P, Kilinç T, Heudi O. HPLC-UV determination of total vitamin $\mathrm{C}$ in a wide range of fortified food products. Food Chemistry. 2006;94(4):626-631.

15. Umesha KB, Kumar KA, Rai KML. Iodometric Determination of Ascorbic acid in bulk and Vitamin-C Tablets using Chloramine-T. Oxidation Communications. 2002;25:566-570. 